\title{
GUIDELINES
}

\section{Chapter 20. Dyslipidemia}

(C) Japanese Society of Nephrology 2009

- Treatment of dyslipidemia in CKD is expected to reduce urinary protein excretion and to suppress kidney function decline.

- In CKD, it is essential to reduce LDL cholesterol level to below $120 \mathrm{mg} / \mathrm{dL}$, and if possible to below $100 \mathrm{mg} / \mathrm{dL}$.

\section{Significance of dyslipidemia control in CKD}

- Successful treatment of dyslipidemia is known to lower CVD risk, and is also expected to retard the decline of kidney function.

- Since statins have been shown to alleviate urinary protein or microalbumin excretion, statins are recommended for CKD with proteinuria.

- Antihyperlipidemic drugs available in Japan and remarks on their use in CKD stages 3-5 are given in Table 20-1.

- Concurrent use of statins and fibrates increases the risk of rhabdomyolysis.
The target for LDL cholesterol (LDL-C) in CKD

- The guidelines for dyslipidemia therapy in CKD from $\mathrm{K} / \mathrm{DOQ} 1$ : below LDL-C $130 \mathrm{mg} / \mathrm{dL}$, the first step is lifestyle modification; above LDL-C $130 \mathrm{mg} / \mathrm{dL}$, drug therapy should be contemplated in addition to lifestyle modification, including diet therapy, weight control, and exercise.

- Evidence-Based Practice Guideline for the Treatment of Diabetes in Japan 2007 recommends that the target for lipid control is less than $120 \mathrm{mg} / \mathrm{dL}$ of LDL-C among diabetic CKD patients. The Guidelines for Prevention of Atherosclerotic Disease in Japan also set the same target for lipid control in a high-risk group (three or more risk factors) or in cases with diabetes, cerebral infarction, or peripheral artery disease. CKD is a critical risk factor for CVD, and thus LDL-C is lowered down to less than $120 \mathrm{mg} / \mathrm{dL}$. If possible, the target for LDL-C should be stricter: less than $100 \mathrm{mg} / \mathrm{dL}$.

- There is not enough evidence relating to the target of dyslipidemia treatment for Japanese patients with CKD. Resolution of this issue must await future studies. 
Table 20-1 Drugs for dyslipidemia that are available in Japan and cautionary remarks regarding their use in CKD

\begin{tabular}{|c|c|c|c|}
\hline Class & General name & Characteristics & Use in low GFR \\
\hline $\begin{array}{l}\text { HMG-CoA reductase } \\
\text { enzyme inhibitors } \\
\text { (statins) }\end{array}$ & $\begin{array}{l}\text { Pravastatin } \\
\text { Simvastatin } \\
\text { Fluvastatin } \\
\text { Atrovastatin } \\
\text { Pitavastatin } \\
\text { Rosuvastatin }\end{array}$ & $\begin{array}{l}\text { Inhibit cholesterol production } \\
\text { in the liver } \\
\text { Strong power to decrease TC, } \\
\text { LDL-C } \\
\text { Adverse reaction: liver } \\
\text { damage, rhabdomyolysis }\end{array}$ & $\begin{array}{l}\text { Main excretory route is bile duct, so it can be used in kidney } \\
\text { damage (Pravastatin is excreted more in the urine). } \\
\text { Rhabdomyolysis may occur, although with low incidence, in } \\
\text { CKD. In CKD stage } 3 \text { and over, careful follow-up is necessary. } \\
\text { Cyclosporine, which is often used in resistant nephrotic } \\
\text { syndrome, may have adverse effects if used simultaneously }\end{array}$ \\
\hline Probucol & Probucol & $\begin{array}{l}\text { Lower TC, LDL-C, but also } \\
\text { lower HDL-C } \\
\text { Antioxidant effect: } \\
\text { antiatherosclerosis } \\
\text { Prolong QT interval in ECG }\end{array}$ & No problems \\
\hline Anion exchange resins & $\begin{array}{l}\text { Colestyramine } \\
\text { Colestimide }\end{array}$ & $\begin{array}{l}\text { Inhibit bile acid circulation } \\
\quad \text { (intestine-liver) } \\
\text { Lower TC, LDL-C }\end{array}$ & No problems \\
\hline Fibrates & $\begin{array}{l}\text { Clinofibrate } \\
\text { Bezafibrate } \\
\text { Fenofibrate }\end{array}$ & $\begin{array}{l}\text { Enhance LPL activity } \\
\text { Lower TG, (very strong) } \\
\text { Increase HDL-C } \\
\text { Rhabdomyolysis } \\
\text { Do not use with statins }\end{array}$ & $\begin{array}{l}\text { Do not use Bezafibrate or Fenofibrate } \\
\text { in kidney failure or dialysis patients } \\
\text { Do not use for CKD stage } 4 \text { and } 5 \\
\text { Clinofibrate can be used with care }\end{array}$ \\
\hline Nicotinic acids & $\begin{array}{l}\text { Niceritrol } \\
\text { Nicomol } \\
\text { Tocopherol } \\
\text { Nicotinate }\end{array}$ & $\begin{array}{l}\text { Lower TG } \\
\text { Lower Lp (a) } \\
\text { Rash in face }\end{array}$ & No problems \\
\hline Others & $\begin{array}{l}\text { Eicosapentaenoic } \\
\text { acid (EPA) }\end{array}$ & $\begin{array}{l}\text { Lower TG } \\
\text { Antiplatelet function: } \\
\text { antiatherosclerosis }\end{array}$ & No problems \\
\hline
\end{tabular}

$T C$ total cholesterol, $L D L-C$ LDL cholesterol, $H D L-C$ HDL cholesterol, $T G$ triglyceride, $L P L$ lipoprotein lipase, $L p(a)$ lipoprotein (a) 